\title{
SPRAY DEPOSITION AND LOSSES IN POTATO AS A FUNCTION OF AIR-ASSISTANCE AND SPRAYER BOOM ANGLE
}

\author{
Fábio Scudeler ${ }^{1}$; Carlos Gilberto Raetano ${ }^{2 *}$ \\ ${ }^{1}$ UNESP/FCA - Programa de Pós-Graduação em Proteção de Plantas. \\ ${ }^{2}$ UNESP/FCA - Depto. de Produção Vegetal - Defesa Fitossanitária, C.P. 237 - 18603-970 - Botucatu, SP - \\ Brasil. \\ *Corresponding author <raetano@fca.unesp.br>
}

ABSTRACT: Within the Brazilian agricultural scene, the potato crop plays a significant economic role. Modern equipment and the development of improved chemical product application techniques contribute toward the constant search for improved revenue from the potato as a crop. Field experiments were carried out in a random block design of a potato crop of the "Ágata" variety. The aim was to evaluate the effect of air assistance combined to different angles of spray application on the chemical deposition on the potato plant, as well as to assess spray losses to the soil. For this a sprayer with and without boom air assistance was used in the experiments. Boom angles of $0^{\circ},+30^{\circ}$ and $-30^{\circ}$ were directed to a vertical position as well as forward and backward movements. The trial plants were sprayed at a volume rate of $400 \mathrm{~L} \mathrm{ha}^{-1}$ using JA-4 hollow cone nozzles at $633 \mathrm{kPa}$ and copper oxychloride as a tracer for the deposit evaluation. Trace deposits on both surfaces of leaflets were removed by washing with destilled water and were quantified by atomic absorption spectrophotometry. Spray losses were measured by placing plastic measuring collectors between rows. The deposit levels at different positions in the plant were analyzed by the Hotelling $\mathrm{T}^{2}$ statistical test. Larger deposits were detected at both upper and lower positions of the plant when the spray boom was positioned at $0^{\circ}$ and $+30^{\circ}$ in the presence of air assistance. The presence of air, in addition to the increasing spray deposits in the lower parts of the plant, helped to create greater distribution uniformity. Spray loss was below $4 \%$.

Key words: Solanum tuberosum, application technology, sleeve boom sprayer, spray

\section{DEPOSIÇÃo E PERDAS NA PULVERIZAÇÃO DA BATATA EM FUNÇÃO DA ASSISTÊNCIA DE AR E ANGULAÇÃO DA BARRA PULVERIZADORA}

\begin{abstract}
RESUMO: A cultura da batata possui grande expressão econômica dentro do cenário agrícola. Para isso, equipamentos e técnicas de aplicação de produtos fitossanitários vêm sendo desenvolvidos visando melhorar o rendimento econômico da cultura. Neste sentido, experimentos foram conduzidos no delineamento em blocos ao acaso na cultura da batata cv. Ágata. Objetivando avaliar o efeito da assistência de ar combinada a diferentes ângulos de aplicação sobre a deposição da pulverização, bem como as perdas da calda para o solo utilizou-se um pulverizador com e sem assistência de ar junto à barra de pulverização posicionada $\mathrm{a}+30^{\circ}, 0^{\circ}$ e $-30^{\circ}$ (sinal + a favor e - contrário ao deslocamento) em relação a vertical. O volume de calda foi $400 \mathrm{~L} \mathrm{ha}^{\circ}$ ${ }^{1}$ utilizando-se pontas de jato cônico vazio JA-4 na pressão de $633 \mathrm{kPa}$. Para a avaliação dos depósitos utilizou-se um traçador cúprico. Os depósitos foram removidos dos folíolos por lavagem com água destilada, em ambas as superfícies foliares, nas posições superior e inferior das plantas de batata e quantificados por espectrofotometria de absorção atômica. As perdas da pulverização foram avaliadas em coletores plásticos colocados nas entrelinhas das parcelas experimentais. Os níveis dos depósitos do traçador cúprico nas diferentes posições da planta foram analisados pelo teste estatístico $\mathrm{T}^{2}$ de Hotteling. Os maiores depósitos foram obtidos com a barra posicionada a $0^{\circ} \mathrm{e}+30^{\circ}$, em presença da assistência de ar, tanto na posição superior quanto inferior da planta. A presença do ar, além de propiciar maiores depósitos na parte inferior das plantas, possibilitou maior uniformidade na distribuição deles. As perdas da pulverização ficaram abaixo de $4 \%$. Palavras-chave: Solanum tuberosum, tecnologia de aplicação, pulverizador de barras com ar, pulverização
\end{abstract}

\section{INTRODUCTION}

To achieve an effective control of potato diseases and to reduce production costs, the techniques and equipment for the application of phytosanitary products must be improved, which in turn enhances spray distribution and placement of the phytosanitary product on the biological target. In order to improve

Sci. Agric. (Piracicaba, Braz.), v.63, n.6, p.515-521, November/December 2006 
the fungicide application to a field crop, sprayers have been equipped with air-assistance booms, which allow a directed spray mix flow thus avoiding drift losses (Cooke et al., 1990; Bauer \& Raetano, 2000). They also provide better product distribution and deposition on the abaxial surface of leaves of the lower parts of the plant (Leonard et al., 2000; Panneton et al., 2000; Venegas, 2002; Scudeler \& Raetano, 2004), increasing the penetration of droplets into the crop canopy (Matthews, 2000), as well as reducing spray deposit variability (Venegas et al., 2003).

Studies involving different nozzle angles of the spray boom have determined that greater spray deposition occurs when the nozzle angle adjustment is turned toward the movement of the equipment (Dorr, 1990; Hislop et al., 1993; Tomazella, 2001; Silva, 2000; Souza et al., 2001; Raetano, 2004; Scudeler \& Raetano, 2004). During spray operations, agrochemical losses may exceed up to $70 \%$ of the total product applied (Chaim et al., 1999a; 1999b; 2000). Other authors have verified losses between $30 \%$ and $50 \%$ (Buisman et al., 1989; Pergher et al., 1999). However, in some cases, deposition on plants has been higher than $64 \%$ of the total applied (Pergher \& Gubiani, 1995).

The objectives of this research were to evaluate the effect of air assistance combined to different angles of application in spray deposition on the potato plant, as well as the evaluation of spray losses to the soil.

\section{MATERIAL AND METHODS}

Two experiments were carried out in the beginning of November 2004, in a commercial potato crop, cv. Ágata, located in São Miguel Arcanjo, SP, Brazil (235' $\left.56^{\prime \prime} \mathrm{S}, 4^{\circ} 52^{\prime} 48^{\prime \prime} \mathrm{W}\right)$ : one evaluated spray deposits of a cupric tracer under different operational conditions, while the other was intended to evaluate spray losses. Plants were spaced at $0.80 \times 0.35$ $\mathrm{m}$ and had a height of approximately $0.50 \mathrm{~m} 58$ days after planting, by the time the experiments were installed. The size of each plot was $8 \mathrm{~m}$ wide (10 planted rows) and $10 \mathrm{~m}$ long. A 5-meter plot divider was left at the end of each plot, thus preventing interference between treatments.

The experiments were conducted in a randomized blocks, $2 \times 3$ factorial design with six treatments: presence and absence of air-assistance on the boom in combination with three application angles, $+30^{\circ}, 0^{\circ}$, and $-30^{\circ}$, where the positive signal indicates direction oriented toward equipment movement and the negative signal indicates direction against movement; in four replicates, using a total of 24 experimental plots.
An Advance Vortex 2000 sprayer, with $18 \mathrm{~m}$ spray boom with all-electric controls was used to carry out both experiments. An electronic controller device was installed in the tractor cockpit allowing the boom angle to be adjusted either towards or contrary to the movement. The equipment also allows spraying to be performed in the presence or absence of air assistance on the boom, in combination with different application angles. The speed of the motor-mechanized assembly was $4.5 \mathrm{~km} \mathrm{~h}^{-1}$. The sprayer, equipped with model JA4 hydraulic hollow cone spray nozzles with working pressure of $633 \mathrm{kPa}$ (nozzle flow of $1.51 \mathrm{~L} \mathrm{~min}^{-1}$ ) provided a $400 \mathrm{~L} \mathrm{ha}^{-1}$ volume application. The temperature, relative humidity, and wind speed at a $1.0 \mathrm{~m}$ high from the soil surface were monitored during the applications by a digital thermo-hygrometer and anemometer, respectively.

A cupric fungicide $\left(840 \mathrm{~g} \mathrm{~kg}^{-1}\right.$ copper oxychloride, equivalent to $50 \%$ metallic copper), at a rate of 200 g c.p. per $100 \mathrm{~L}$ water was used as a tracer, applied on the corresponding plots by spraying with only $50 \%$ of the boom section. However, air speed $(100 \mathrm{~km}$ $\left.\mathrm{h}^{-1}\right)$ and volume $\left(40,020 \mathrm{~m}^{3} \mathrm{~h}^{-1}\right)$ were maintained along the entire boom, due to maximum fan rotation.

Plants were divided in two sampling positions: above (upper) and below (lower) $0.25 \mathrm{~m}$ height to evaluate spray deposition. Ten plants were sampled per plot (one plant per row) along the direction of the equipment movement and depositions were evaluated on natural targets (potato leaflets).

After the tracer application, one sample from the lower section and another one from the upper section of each sampled plant were collected. Samples were taken from each sampling section to quantify the deposits on the potato leaflet's adaxial and abaxial surfaces, using a metallic sampler instrument developed for this procedure (Figure 1), inverted "W"-shaped, with a metallic support containing two orifices facing to each other, positioned at the proximal end thus allowing the adaxial and abaxial leaflet surfaces to be washed simultaneously.

When the sampler shank ends are brought close together, they hold the leaflet fastened between the orifices, which are interconnected by metallic channels to the tool distal ends. At the distal part of each sampler shank, $20 \mathrm{~mL}$ capacity vials were connected by a thread; at the end of the shank they are brought close together, so that they allow the washing liquid to be in contact with both leaf surfaces to remove the tracer. When the ends are pulled apart, the liquid returns to its corresponding collecting vials which are connected to the distal parts of the sampler. The casual contamination from a previous sample with solution remaining on the ring, in the tubes or in the vials 

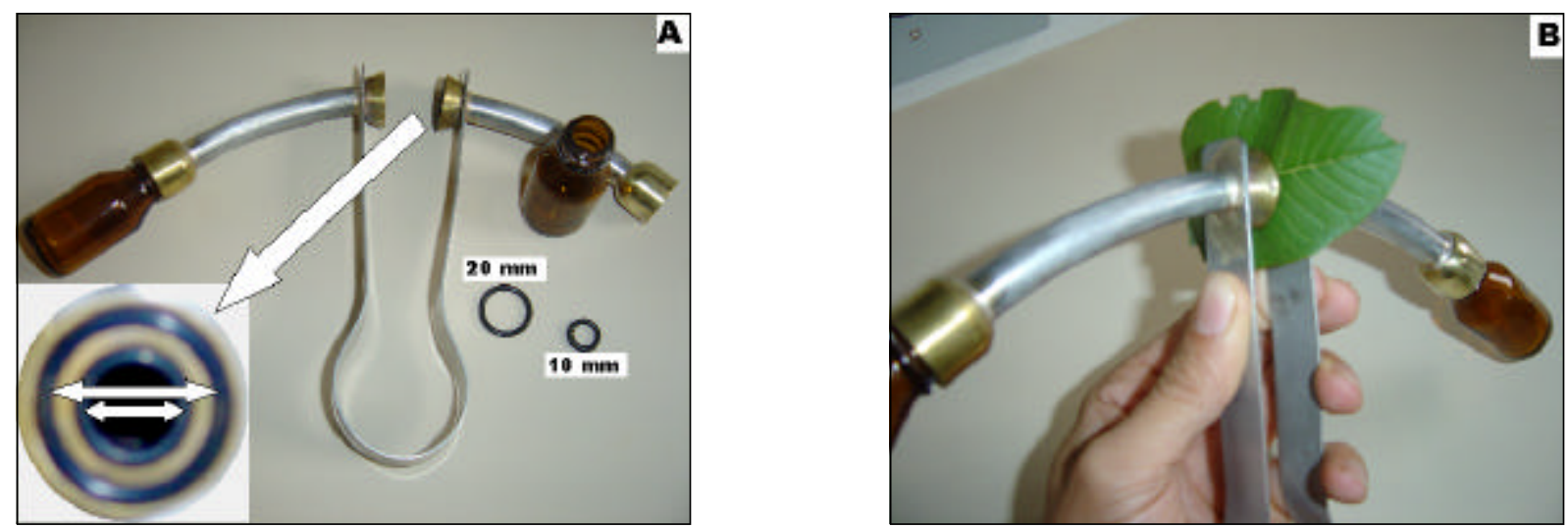

Figure 1 - Metallic device used to sample spray deposits on potato leaflet surfaces: A) washing area delimiter rings; B) leaflet attached to shanks in order to be washed.

was avoided by washing of the sampler instrument with distilled water before each sampling.

The sampled leaflets were selected at random, standardizing the sampling operation by selecting a point in the central part of each leaflet where the sampler was to be used. The sampling area on the leaf surface may vary as a function of the removal of two concentric sealing rings, which are set to a 10 or $20 \mathrm{~mm}$ diameter limit for the washed area (Figure $1 \mathrm{~A}$ ).

In order to remove the tracer, $10 \mathrm{~mL}$ of distilled water were placed into each vial positioned at the distal part of the sampling instrument, and the simultaneous washing of the adaxial and abaxial potato leaflet surfaces was achieved by synchronized clockwise and counterclockwise turning movements of a quarter turn (Figure $1 \mathrm{~B}$ ). The washing solution from each sample was forwarded to the laboratory for the analysis of the deposits by atomic absorption spectrophotometry, in order to determine the amount of the copper ion at the wave lenght of $324.754 \mathrm{~nm}$. The limit of detection and integration time were of $0.002 \mathrm{mg} \mathrm{L}^{-1}$ and two seconds, respectively. Thus, the results were expressed as mean deposition values $\left(\mathrm{mg} \mathrm{L}^{-1}\right)$ for each sample.

Since the concentration of copper in the mix was known, it was possible to establish the net captured volume (Equation 1).

$$
\mathrm{C}_{\mathrm{i}} \cdot \mathrm{V}_{\mathrm{i}}=\mathrm{C}_{\mathrm{f}} \cdot \mathrm{V}_{\mathrm{f}}
$$

where: $\mathrm{C}_{\mathrm{i}}=$ copper concentration in the mix $\left(\mathrm{mg} \mathrm{L}^{-1}\right)$; $\mathrm{C}_{\mathrm{f}}=$ copper concentration detected in the spectrophotometer $\left(\mathrm{mg} \mathrm{L}^{-1}\right) ; \mathrm{V}_{\mathrm{i}}=$ volume captured in the sample $(\mu \mathrm{L})$; and $\mathrm{V}_{\mathrm{f}}=$ sample dilution volume $(\mu \mathrm{L})$

By knowing the diameter of the collector orifice, in this case $20 \mathrm{~mm}$, the tracer volume captured per $\mathrm{cm}^{2}$ of leaf area can be established. For the evaluation of losses to the soil, plastic collectors of $100 \mathrm{~cm}^{2}$ were initially distributed between rows in the experi- mental plots. Next, the cupric tracer was applied at a rate previously established. No other fungicide was applied before cupric tracer application. After the application, the content captured in the collectors was washed with $10 \mathrm{~mL}$ distilled water and stored in a glass vial for later analysis of the deposits by atomic absorption spectrophotometry.

Using Equation 1, the net captured volume per plate was established, and based on the known area the captured volume per $\mathrm{cm}^{2}$ was calculated; the value thus obtained represented the amount of spray that was lost between rows of the crop. The tracer deposit values quantified by atomic absorption spectrophotometry were submitted to analysis at the $1 \%$ significance level (Wichern \& Johnson, 1992), by the PERFIL computer software (Rosa, 1994). The spray loss values, also quantified by the same methodology, were submitted to analysis of variance by the $\mathrm{F}$ test, complemented by the Tukey comparison test at 5\% significance level.

\section{RESULTS AND DISCUSSION}

The meteorological data at the moment of the applications, indicated adequate levels for the application process, with temperature, relative humidity, and wind speed values between 21.4 and $24.8^{\circ} \mathrm{C}, 48.3$ and $60.1 \%$, and 2.9 and $5.8 \mathrm{~km} \mathrm{~h}^{-1}$, respectively. The mean values of deposits obtained from the cupric tracer on the adaxial surface, at both upper and lower positions, of the Ágata potato variety plants are presented in Table 1.

The $30^{\circ}$ angle oriented toward equipment movement, regardless of the application condition, and the $0^{\circ}$ angle with air assistance favored deposition on the lower position of potato plants, in contrast to the $-30^{\circ}$ angle (oriented against sprayer movement) and the $0^{\circ}$ angle without air assistance, which obtained an average of $50 \%$ less deposits on the lower position than 
on the upper position of the plants (upper case letters, on rows in Table 1). Panneton et al. (2000) also verified that air assistance modifies the vertical gradient of deposits, providing better uniformity in the deposition at different positions within potato plants.

Occurrence of greater deposits on the lower position of potato plants by using spray boom angled at $30^{\circ}$ in the presence or absence of air assistance and at $0^{\circ}$ with air assistance was due to spray dynamics during the movement of the equipment. Fine and very fine droplets with smaller momentum receive supplemental energy by air assistance, providing high spray penetration into the crop and modifying the vertical gradient of deposits within potato plants. An adverse effect was obtained when the spray boom was oriented against sprayer movement $\left(-30^{\circ}\right)$, because of the maintenance of smaller droplets longer in suspension and consequently increasing the spray losses.

Comparing the conditions of application (lower case letters in Table 1) - equipment with or without air assistance - with fixed sampling position and spray boom angle, it can be verified, in general, that greater deposits occurred on the adaxial surface of potato leaflets when the spraying with cupric tracer was performed in the presence of air assistance, except for the $-30^{\circ}$ spray boom angle, for which a greater deposit was obtained without air assistance (Table 1). While the deposits at the upper position of plants were 57 and $60 \%$ for the +30 and $0^{\circ}$ angles, respectively, the deposits at the lower position were 62 and 79\%, respectively, for the same angles, in the air assistance presence when compared at the same angles in the absence of this technology.

Comparing the spray boom angles (Greek letters in Table 1), when the application condition and sampling position were fixed, it was verified that greater deposits were obtained at $0^{\circ}$ angles in relation to the upright and at $30^{\circ}$ toward the movement of the motorized assembly in the presence of air assistance, for which deposits were 62 and $86 \%$ higher at the upper and lower positions, respectively. The same fact could not be observed at a $30^{\circ}$ angle on the spray boom against equipment movement, since there were no statistical differences between these treatments. Similar results were obtained by Bauer (2002), when greater spray deposits were detected for the spray boom angled towards the spray equipment movement, for soybeans, especially at $45^{\circ}$ towards the movement of the equipment, 45 days after emergence.

In general, air assistance did not influence deposition on the abaxial surface of potato leaflets at the lower position in the plants (Table 2); even so the depositions at both sections were similar (upper case letters in Table 2).

The combination between air assistance and the $+30^{\circ}$ angle provided a deposition increase in the order of 74 and $75 \%$, respectively, for upper and lower positions in the plant, while for $0^{\circ}$ angle the increasing deposition was of the order of 85 and $84 \%$, respectively, for the upper and lower positions when compared at the same angles, for air assistance absence, in accordance to results obtained by Panneton et al. (2000) and Leonard et al. (2000). For the $-30^{\circ}$ angle, a completely divergent fact occurred: deposition without air assistance was greater on the abaxial surface than with air assistance, both at the higher and at the lower positions. This could be explained in part by the increase in the number of droplets with a tendency to drift as a consequence of the combination of this operational condition $\left(-30^{\circ}\right.$ with air assistance) with displacement speed, therefore increasing losses.

Comparing the application angles with fixed conditions (with or without air) and sampling position in the plant, it was possible to observe that at the $+30^{\circ}$ and $0^{\circ}$ angles associated with air assistance provided a $90 \%$ increase in deposits at the upper position and

Table 1 - Mean \pm standard deviation of cupric tracer deposits on the adaxial surface of potato leaflets at the upper and lower positions of the plants. São Miguel Arcanjo-SP, Brazil, 2004.

\begin{tabular}{lccccc}
\hline Condition & Angle & \multicolumn{2}{c}{ Upper } & \multicolumn{2}{c}{ Lower } \\
\hline With air & \multicolumn{3}{c}{$\mu \mathrm{L} \mathrm{cm}^{-2}$} & \multicolumn{4}{c}{$\mu \mathrm{cm}^{-2}$} \\
With air & $0^{\circ}$ & $2.5224 \pm 0.5247$ & A a $\alpha$ & $1.9523 \pm 0.6385$ & A a $\alpha$ \\
With air & $+30^{\circ}$ & $2.3404 \pm 0.5567$ & A a $\alpha$ & $2.1137 \pm 0.5154$ & A a $\alpha$ \\
Without air & $-30^{\circ}$ & $1.4151 \pm 0.6780$ & A a $\alpha$ & $0.5977 \pm 0.2438$ & B a $\alpha$ \\
Without air & $0^{\circ}$ & $1.0063 \pm 0.4191$ & A b $\alpha$ & $0.4166 \pm 0.1607$ & B b $\beta$ \\
\hline Without air & $+30^{\circ}$ & $1.0093 \pm 0.2542$ & A b $\alpha$ & $0.8171 \pm 0.2877$ & A b $\alpha$ \\
\hline
\end{tabular}

${ }^{1}$ upper case letters compare sampling positions with a fixed application condition and spray boom angle. ${ }^{2}$ lower case letters compare application conditions with fixed spray boom angle and sampling positions. ${ }^{3}$ Greek letters compare spray boom angles with fixed application condition and sampling positions. Common letters are not different among themselves by Hotelling $\mathrm{T}^{2}$ test at the $1 \%$ significance level. 
Table 2 - Mean \pm standard deviation of cupric tracer deposits on the abaxial surface of potato leaflets at the upper and lower positions of the plants. São Miguel Arcanjo-SP, Brazil, 2004.

\begin{tabular}{|c|c|c|c|c|c|}
\hline \multirow{2}{*}{ Condition } & \multirow[t]{2}{*}{ Angle } & \multicolumn{2}{|c|}{ Upper } & \multicolumn{2}{|c|}{ Lower } \\
\hline & & $\mu \mathrm{L} \mathrm{cm}{ }^{-2}$ & & $\mu \mathrm{L} \mathrm{cm}^{-2}$ & \\
\hline With air & $-30^{\circ}$ & $0.0407 \pm 0.0346$ & $\mathrm{~A}^{1} \mathrm{~b}^{2} \beta^{3}$ & $0.0519 \pm 0.0655$ & $\mathrm{~A} b \beta$ \\
\hline With air & $0^{\circ}$ & $0.3696 \pm 0.1035$ & A a $\alpha$ & $0.3206 \pm 0.0966$ & A a $\alpha$ \\
\hline With air & $+30^{\circ}$ & $0.4224 \pm 0.1024$ & A a $\alpha$ & $0.3607 \pm 0.0610$ & A a $\alpha$ \\
\hline Without air & $-30^{\circ}$ & $0.1254 \pm 0.0302$ & A a $\alpha$ & $0.1201 \pm 0.0605$ & A a $\alpha$ \\
\hline Without air & $0^{\circ}$ & $0.0541 \pm 0.0267$ & $\mathrm{~A}$ b $\beta$ & $0.0526 \pm 0.0215$ & $\mathrm{~A} \mathrm{~b} \alpha$ \\
\hline Without air & $+30^{\circ}$ & $0.1104 \pm 0.0430$ & A b $\alpha$ & $0.0881 \pm 0.0231$ & $\mathrm{~A} b \alpha$ \\
\hline
\end{tabular}

${ }^{1}$ upper case letters compare sampling positions with a fixed application condition and spray boom angle. ${ }^{2}$ lower case letters compare application conditions with fixed spray boom angle and sampling positions. ${ }^{3}$ Greek letters compare spray boom angles with fixed application condition and sampling positions. Common letters are not different among themselves by Hotelling $\mathrm{T}^{2}$ test at the $1 \%$ significance level.

an $85 \%$ increase in deposits at the lower position, when compared with the $-30^{\circ}$ angle under the same application condition (Table 2).

When spraying deposition was related to the adaxial and abaxial surfaces of potato leaflets (Figure 2), the same deposition can be obtained on both sides of the potato leaflets at both sampling locations with the use of air assistance and a spray boom angle of $+30^{\circ}$. For the lower position when the $0^{\circ}$ angle is used with air assistance, the smaller spray deposition on the abaxial surface ( $80 \%$ of adaxial surface deposits) can be explained due to the fact that the air generated by the fan hits the crop canopy vertically.

Soil contamination by sprays can be greatly reduced when air-assisted sprayers are used (Taylor \& Andersen, 1997). The density, architecture, and development stage of the plant species in the target area are factors that influence losses to the soil; this also happens for the potato crop. In spite of the environmental condition and copper ion concentration differences, it is worthwhile to compare these deposition values with those obtained by Venegas (2002), who used varieties Bintje and Asterix instead of Ágata, which additionally explains the effect of the different architecture of the varieties, since their development stages were similar. The interaction between factors 'application condition' (with or without air) and 'boom angle' was not significant at $5 \%$ probability (Table 3 ). This demonstrates that both factors act in an independent manner over spray losses.

The spray losses to the soil after application of a cupric tracer on the potato plant are presented in Table 4. There was no difference between the operational conditions evaluated and losses to the soil were below $4 \%$. The spray loss percentage to the soil was smaller in relation to the one obtained by Bauer \& Raetano (2000) for soybean at the R6 developmental stage, varying from 15 to $18.9 \%$ inside the crop canopy.

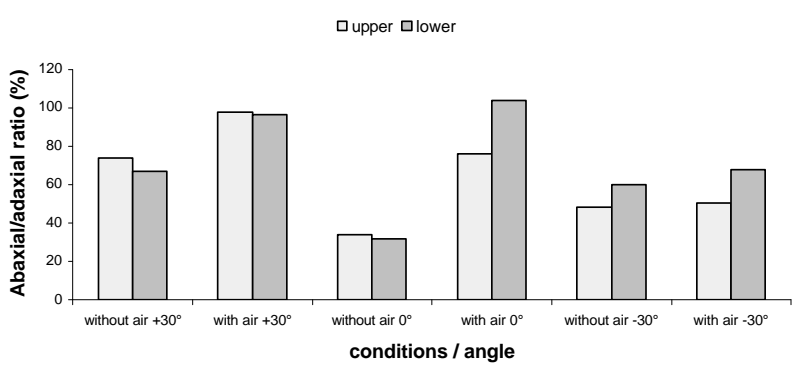

Figure 2 - Relationship between abaxial/adaxial surface deposits on leaflets at the upper and lower positions in potato plants, Ágata variety, after spray with a cupric tracer 58 days after planting.

The minimum losses observed in this study are a consequence of the influence of the target-plant type, as well as its developmental stage, as previously mentioned. Fifty eight days after planting, the potato plants had an average height of $0.5 \mathrm{~m}$, which gives the crop a leaf area index (LAI) between 5 and 7, based on its degree of leaf cover. Smaller levels of tracer deposition found in the soil with air assistance are probably due to an increased plant displacement which creates a barrier of leaves and thus improves interception of the spray. In contrast to such an observation, when the spray boom was placed at $-30^{\circ}$ angle (oriented against sprayer movement) sedimentation and air transport drift were improved.

The potato plant as a crop has innumerable limitations in relation to technological applications used in phytosanitary control. As these studies advance, the technological development of the crop can be aided, thus allowing for an increase of productivity.

The study herein conducted took into account new technologies that may be successfully employed in the application of phytosanitary products on potato plants. The spray boom angle of attack, assisted by an air curtain, provided significant gains of spray depo- 
Table 3 - Analysis of variance for spray losses for Ágata variety potato, 58 days after planting. São Miguel Arcanjo - SP, Brazil, 2004.

\begin{tabular}{lcc}
\hline Causes of variation & DF & F \\
\hline Condition (C) & 1 & $4.44 \mathrm{~ns}^{1}$ \\
Angle (A) & 2 & $0.67 \mathrm{~ns}$ \\
$\mathrm{C} \times \mathrm{A}$ & 2 & $1.59 \mathrm{~ns}$ \\
\hline Blocks & 3 & $1.02 \mathrm{~ns}$ \\
Treatments & 5 & $1.79 \mathrm{~ns}$ \\
Residue & 15 & \\
\hline
\end{tabular}

${ }^{1}$ non-significant $(P<0.05)$.

Table 4 - Spray losses as a function of different operational conditions Ágata variety potato, 58 days after planting. São Miguel Arcanjo - SP, Brazil, 2004.

\begin{tabular}{lccc}
\hline Condition & Angle & Losses & Losses \\
\hline & & $\mu \mathrm{L} \mathrm{cm}^{-2}$ & $\%$ \\
With air & $-30^{\circ}$ & $0.1496 \mathrm{~A}^{1}$ & 3.74 \\
With air & $0^{\circ}$ & $0.0706 \mathrm{~A}$ & 1.77 \\
With air & $+30^{\circ}$ & $0.0799 \mathrm{~A}$ & 2.00 \\
Without air & $-30^{\circ}$ & $0.1687 \mathrm{~A}$ & 4.22 \\
Without air & $0^{\circ}$ & $0.1484 \mathrm{~A}$ & 3.71 \\
Without air & $+30^{\circ}$ & $0.1396 \mathrm{~A}$ & 3.49 \\
\hline MSD & 0.1395 & & \\
CV & 48.10 & & \\
\hline
\end{tabular}

${ }^{1}$ means followed by the same letter in the column are not different among themselves by Tukey test, at a 5\% significance level.

sition when sampled by means of the methodology herein described. The spray mix collection, performed simultaneously at both leaf surfaces, made it possible to establish a quality index for spraying systems, once most of the pest-targets (insects and diseases) can be found on the abaxial surface of cultivated plants. Phytosanitary products with a contact mode of action on the target, less expensive to agricultural producers, may be used more effectively, because when suitable spray system configurations are adopted, better spray depositions can be obtained on the abaxial surface of leaves, increasing productivity. This fact had been previously reported by Venegas et al. (2003) when spray boom air assistance was used on the Bintje variety of potato.

\section{CONCLUSIONS}

Air assistance in the spray boom angled towards the spray equipment movement improves spray deposits on potato plants and changes the vertical gradient, providing uniformity to the application. The $0^{\circ}$ and $+30^{\circ}$ spray boom angles of attack in the presence of air assistance provided the greatest spray deposits on the abaxial surface of potato leaflets. Spray losses to the soil, 58 days after planting the Ágata variety were lower than $4 \%$, for a $400 \mathrm{~L} \mathrm{ha}^{-1}$ spray rate.

\section{ACKNOWLEDEGMENTS}

To CAPES for financial support. To Máquinas Agrícolas Jacto S.A. for technical support and Leandro Hitoshi Fugikawa for the participation in the experiments.

\section{REFERENCES}

BAUER, F.C. Distribuição e deposição da pulverização sob diferentes condições operacionais na cultura da soja [Glycine $\max (\mathrm{L}$.) Merrill]. Botucatu: FCA/UNESP, 2002. 130p. (Tese - Doutorado).

BAUER, F.C.; RAETANO, C.G. Assistência de ar e perdas na deposição de produtos fitossanitários em pulverizações na cultura da soja. Scientia Agricola, v.57, p.271-276, 2000.

BUISMAN, P.; SUNDARAM, K.M.S.; SUNDARAM, A.; TRAMMEL, K. Field deposit patterns of a diflubenzuron spray mix, after application to apple orchard using an air-blast sprayer, and a laboratory evaluation of physical properties and atomization characteristics. Journal of Environmental Science and Health, v.24, p.389-411, 1989.

CHAIM, A.; CASTRO, V.L.S.S.; CORRALES, F.; GALVÃO, J.A.H.; CABRAL, O.M.R. Método para monitorar perdas na aplicação de agrotóxicos na cultura do tomate. Pesquisa Agropecuária Brasileira, v.34, p.741-747, 1999a.

CHAIM, A.; VALARINI, P.J.; OLIVEIRA, D.A.; MORSOLETO, R.V.; PIO, L.C. Avaliação de perdas de pulverização em culturas de feijão e tomate. Jaguariúna: Embrapa Meio Ambiente, 1999b. 29p. (Boletim de Pesquisa, 2).

CHAIM, A.; VALARINI, P.J.; PIO, L.C. Avaliação de perdas na pulverização de agrotóxicos na cultura do feijão. Pesticidas. Revista de Ecotoxicologia e Meio Ambiente, v. 10, p.65-74, 2000.

COOKE, B.K.; HISLOP, E.C.; HERRINGTON, P.J.; WESTERN, N.M.; HUMPHERSON-JONES, F. Air-assisted spraying of arable crops, in relation to deposition, drift and pesticide performance. Crop Protection, v.9, p.303-311, 1990.

DORR, G.J. The effect of orientation and fan angle on spray deposition by flat fan noozles. In: AGRICULTURAL ENGINEERS CONFERENCE, 1990. Toowoomba, 1990. Proceedings. Toowoomba, 1990. p.30-32.

HISLOP, E.C.; WESTERN, B.K.; COOKE, B.K.; BUTLER, R. Experimental air-assisted spraying of young cereal plants under controlled conditions. Crop Protection, v.12, p.193-200, 1993.

LEONARD, R.; RICE, B.; DOWLEY, L.J.; WARD, S. The effect of air assistance on spray deposition and biological effect in the control Phytophthora infestans in potatoes. Aspects of Applied Biology, v.57, p.243-249, 2000.

MATTHEWS, G.A. Pesticide applications methods. 3.ed. Malden: Blackwell Science, 2000. 432p.

PANNETON, B.; PHILION, H.; THERIALT, R.; KHELIFI, M. Spray chamber evaluation of air-assisted spraying on potato plants. Transactions of ASAE, v.43, p.529-534, 2000.

PERGHER, G.; GUBIANI, R. The effect of spray application rate on foliar deposition in a hedgerow vineyard. Journal of Agricultural Engineering Research, v.61, p.205-216, 1995.

PERGHER, G.; ZUCCHIATTI, N.; GUBIANI, R. Influence of spray application parameters on the position in as asparagus crop. Journal of Agricultural Engineering Research, v.73, p.19-28, 1999.

RAETANO, C.G. Assistência de ar em pulverizadores de barras. In: RAETANO, C.G.; ANTUNIASSI, U.R. (Ed.). Qualidade em tecnologia de aplicação. Botucatu: FEPAF, 2004. p.8-18. 1 CDROM. 
ROSA, G.J.M. Desenvolvimento de aplicativo para análise de perfil na experimentação zootécnica. Botucatu: FMVZ/UNESP, 1994. 72p. (Dissertação - Mestrado).

SCUDELER, F.; RAETANO, C.G. Assistência de ar e angulação da barra pulverizadora na deposição e perdas da pulverização na cultura da batata. Botucatu: FCA/UNESP, 2004. 35p. (Relatório Científico).

SILVA, M.A.S. Depósitos da calda de pulverização no solo e em plantas de tiririca (Cyperus rotundus L.) em diferentes condições de aplicação. Botucatu: FCA/UNESP, 2000. 57p. (Tese - Doutorado).

SOUZA, R.T.; VELINI, E.D.; MACIEL, C.D.G.; COSTA, A.G.F.; SILVA, M.A.S. Depósito de calda de pulverização sobre Cyperus rotundus em função do posicionamento dos bicos de pulverização. In: SIMPÓSIO INTERNACIONAL DE TECNOLOGIA DE APLICAÇÃO DE AGROTÓXICOS: EFICIÊNCIA, ECONOMIA E PRESERVAÇÃO DA SAÚDE HUMANA E DO AMBIENTE, 2., Jundiaí, 2001. Anais... Jundiaí: Instituto Agronômico, Centro de Mecanização e Automação Agrícola, 2001. 6p. Disponível em: http:/ /www.iac.br/ cma/Sintag/num16a_1a.PDF. Acesso em: 07 fev. 2003.

TAYLOR, W.A.; ANDERSEN, P.G. A review of benefits of air assisted spraying trial in arable crops. Aspects of Applied Biology, v.48, p.163-174, 1997.
TOMAZELLA, M.S. Efeitos do estádio de desenvolvimento de Brachiaria plantaginea (Link) Witc., ângulo de aplicação e tipo de ponta na deposição da calda de pulverização. Botucatu: FCA/UNESP, 2001. 53p. (Tese - Doutorado).

VENEGAS, F. Assistência de ar em barra de pulverização, deposição da calda e controle da pinta preta na cultura da batata. Botucatu: FCA/UNESP, 2002. 76p. (Dissertação - Mestrado).

VENEGAS, F.; RAETANO, C.G.; BAUER, F.C. Assistência de ar em barra de pulverização, deposição da calda e controle da pinta preta na cultura da batata. Summa Phytopathologica, v.29, p.323-329, 2003.

WICHERN, D.; JOHNSON, R.A. Applied multivariate statistical analysis. 3.ed. New Jersey: Prentice Hall, 1992. 642p.

Received November 18, 2005

Accepted October 18, 2006 